\title{
Technologies for fixed-time artificial insemination and their influence on reproductive performance of Bos indicus cattle
}

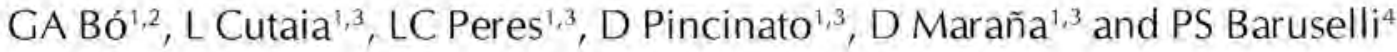 \\ Instituto de Reproducción Animal Córdoba (IRAC), J.L. de Cabrera 106, X5000GVD, Córdoba, \\ Argentina, ${ }^{2}$ Universidad Católica de Córdoba, ${ }^{3}$ Universidad Nacional de Córdoba, ${ }^{4}$ Departamento de \\ Reprodução Animal, FMVZ-USP, Brazil.
}

The adaptation of Bos indicus cattle to tropical and subtropical environments has led to their widespread distribution around the world. Although artificial insemination ( $\mathrm{Al}$ ) is one of the best alternatives to introduce new genetics into Bos indicus herds, the peculiarity of their temperament and the tendency to show short oestrus (many of them during the night) greatly affects the effectiveness of genetic improvement programs. Therefore, the most useful alternative to increase the number of females that are inseminated is the use of protocols that allow for $\mathrm{Al}$ without the need for oestrus detection, usually called fixed-time AI (FTAI). Besides, the development of protocols to advance the resumption of cyclicity during the early postpartum period has a great impact on beef production and will allow for the inclusion of a significantly larger population of animals into genetic improvement programs. Fixed-time Al protocols using progestin devices, oestradiol and eCG have resulted in consistent pregnancy rates in suckled Bos indicus and Bos indicus $x$ Bos taurus cows. Furthermore, fertility in the successive cycles and the overall pregnancy rates at the end of the breeding season, have been shown to be improved by the use of progestin devices at the beginning of the breeding season. In summary, exogenous control of luteal and follicular development has facilitated the application of assisted reproductive technologies in Bos indicus-influenced cattle, by offering the possibility of planning programs without the necessity of oestrus detection and may provide the opportunity to improve reproductive performance of beef cattle in tropical climates.

\section{Introduction}

Most beef herds are located in tropical regions where Bos indicus breeds predominate. Data on reproductive performance, such as calving rate, calf survival and weaning rate have indicated both inferior and superior results for Bos indicus cattle (Chenoweth 1994). However, there is little doubt that Bos indicus breeds, and their crosses, are superior to Bos taurus cattle when they are both kept in tropical or subtropical environments, where stressors such as high tem- 
peratures and humidity, ectoparasites and low quality forages predominate. Artificial insemination is one of the best alternatives to introduce new genetics into Bos indicus herds (especially from Bos taurus breeds); however, only a small percentage of beef animals are subjected to Al. In Argentina for example, only $4.5 \%$ of the beef breeding females are artificially inseminated and $80 \%$ of those are heifers (Marcantonio 2003). Among the main factors that affect the extensive use of $\mathrm{Al}$ in the beef herd are those related to nutrition, management and inefficient oestrus detection. The most useful alternative to significantly increase the number of animals involved in $\mathrm{Al}$ programs is the use of protocols that allow for Al without the need for oestrus detection, usually called fixed-time AI (FTAI) protocols. Also, the development of protocols for suckled cows will allow for the inclusion of a significantly larger population of animals, and not just limit the application of these technologies to heifers. The intention of this manuscript is to present data from studies in which current methods of manipulation of follicular waves and ovulation for FTAI have been successfully applied in Bos indicus and Bos indicus x Bos taurus crossbred herds, and discuss how these protocols may impact the overall fertility of these herds, paying particular attention to those currently applied in extensively managed Bos indicus or Bos indicus x Bos taurus crossbred herds in South America.

\section{Oestrous behaviour and reproductive physiology in Bos indicus cattle}

The characteristics of the oestrous cycle and follicular dynamics in Bos indicus cattle have been recently reviewed (Bó et al. 2003). Bos indicus cattle usually have a very particular temperament that makes oestrus detection a very difficult task. "Silent" or "missed" heats have been reported, after a regular oestrus detection (Galina and Arthur 1990; Galina et al. 1996). Furthermore, duration of oestrus has been reported to be shorter in Bos indicus than in Bos taurus cattle (Galina and Arthur 1990). The average duration of standing oestrus in Bos indicus cattle has been shown to be about $10 \mathrm{~h}$, with variations between 1.3 to $20 \mathrm{~h}$ (Galina and Arthur 1990; Barros et al. 1995; Pinheiro et al. 1998). Other studies utilizing radiotelemetry have confirmed that crossbred Bos indicus x Bos taurus females have a shorter duration of oestrus (approximately 10 h; Bertam Membrive 2000; Rocha 2000), and found more mounting activity during the night $(56.6 \%)$. These findings are in agreement with the results obtained by Pinheiro et al. (1998), who reported $53.8 \%$ of the oestrous expression at night, with $30.7 \%$ of these beginning and ending during the night. Mizuta (2003), using radiotelemetry, found that the mean duration of standing oestrus was $3.4 \mathrm{~h}$ shorter in Nelore (12.9 h) and Nelore x Angus crossbred (12.4 h) than in Angus (16.3 h) cows. However, the interval from the onset of oestrus to ovulation was $27.1 \pm 3.3 \mathrm{~h}$ and $26.1 \pm 6.3 \mathrm{~h}$ in Nelore and Angus cows, respectively (Mizuta 2003). Thus, the interval from the onset of oestrus to ovulation in Bos taurus and Bos indicus cows would not appear to differ.

Several studies have also characterized follicular-wave dynamics in Bos indicus cattle (reviewed in Bó et al. 2003). Bos indicus cattle have two, three or four waves of follicular growth during their oestrous cycle and have a smaller diameter of the dominant follicle and corpus luteum (CL; Bó et al. 2003) and lower serum progesterone concentrations (Seger son et al. 1984) relative to those of Bos taurus cattle.

In more recent studies, the diameter of the dominant follicle at the time of deviation has been reported to be smaller in Nelore ( 6.0 to $6.3 \mathrm{~mm}$, Sartorelli et al. 2005; Gimenes et al. 2005b) than in Holstein ( $8.5 \mathrm{~mm}$; Ginther et al. 1996) cattle. Futhermore, the diameter at which the dominant follicle acquired the capacity to ovulate in response to a treatment with $\mathrm{pLH}$ (Lutropin-V, Bioniche Animal Health, Canada) in Nelore heifers was found to be between 7 and $8.4 \mathrm{~mm}$ (Gimenes et al. 2005a); whereas, it was $10 \mathrm{~mm}$ in Holstein cows (Sartori et al. 2001). 
Seasonality has also been shown to affect cyclicity in Bos indicus cattle. Randel (1984) reported that Bos indicus cows had a decreased incidence of preovulatory $\mathrm{LH}$-surges and their luteal cells in vitro were less responsive to $\mathrm{LH}$ during the winter. Furthermore, conception rates of Brahman cattle were higher in the summer $(61 \%)$ than in the fall $(36 \%$; Randel 1994). Stahringer etal. (1990) and McGowan (1999) also reported an increased occurrence of anoestrus and anovulatory oestrus in Brahman females during the winter.

\section{Physiology of the postpartum period}

Following parturition, there is a dramatic increase in $\mathrm{FSH}$ that is followed by the emergence of the first follicular wave (2 to $7 \mathrm{~d}$ postpartum; reviewed in Wiltbank et al. 2002). However, ovulatory capacity of the dominant follicle only occurs when it is exposed to adequate LHpulse frequency (approximately 1 pulse/hour) to grow and increase oestradiol production, which will result in an LH surge and ovulation (reviewed in Wiltbank et al. 2002). Gonadotrophin secretion patterns in the postpartum period have been shown to differ between Bos taurus and Bos indicus cattle. Thirty days after calving, Hereford $\mathrm{x}$ Shorthorn suckled cows had higher plasma LH concentrations $(0.7 \pm 0.1 \mathrm{ng} / \mathrm{ml})$ than suckled Brahman cows $(0.6 \pm 0.1 \mathrm{ng} / \mathrm{ml})$ and this difference appeared to increase over time (D'Occhio et al. 1990). In addition, a higher proportion of Bos taurus cows had greater pulsatile LH secretion than Bos indicus cows (D'Occhio et al. 1990). Futhermore, a greater proportion of Bos taurus cows became pregnant during mating between 50 to $120 \mathrm{~d}$ after calving compared to Brahman cows. In this study, circulating concentrations of $\mathrm{LH}$ were also affected by body condition and postpartum management (D'Occhio et al. 1990), confirming the notion that nutrition is one of the major factors affecting postpartum ovarian activity in cattle. In that regard, Ruiz-Cortez and Olivera-Angel (1999) observed that Bos indicus suckled cows kept on natural pasture in Colombia re-established their cyclicity from 217 to $278 \mathrm{~d}$ after calving. During the first 6 months after parturition, many of these cows had only small follicles $(<6 \mathrm{~mm}$ in diameter, exceptionally $8 \mathrm{~mm}$ ). From 7 to 12 months postpartum, follicular waves were more regular and when cyclicity re-commenced at 217 to $278 \mathrm{~d}$ postpartum, oestrus preceded ovulation in $43 \%$ of the cases and cows had normal $(21.0 \pm 3.0 \mathrm{~d})$, short $(10.0 \pm 2.0 \mathrm{~d})$ or long $(50.0 \pm 4.0 \mathrm{~d})$ first oestrous cycles. This condition may not be uncommon in Bos indicus cattle and has to be taken into consideration when deciding to begin an Al program. Cows in low body condition would rarely respond to oestrus synchronization treatments (Wiltbank et al. 2002; Bó et al. 2002a; 2002b).

\section{Synchronization of oestrus and ovulation}

Prostaglandin $F 2 \alpha$

Prostaglandin F2 $\alpha$ (PGF) has been the most commonly used treatment for synchronization of oestrus in cattle (Odde 1990). However, the variable interval from PGF treatment to expression of oestrus and ovulation (Kastelic \& Ginther 1991) makes oestrus detection essential to attain high pregnancy rates in Al programs. In Bos indicus cattle, oestrus response was about $30 \%$ less than that reported for Bos taurus cattle under the same conditions (reviewed in Galina and Arthur 1990). In two other studies, although 80 to $100 \%$ of the cows treated with PGF had luteal regression, only 29 to $60 \%$ were detected in oestrus (Moreno et al. 1986; Alonso et al. $1995)$ and $51 \%(29 / 57)$ ovulated (Alonso et al. 1995) within $5 \mathrm{~d}$ of treatment. The combination of low and variable oestrus response and the high incidence of anoestrus common in animals grazing tropical grasses explain the wide variability in oestrus response and pregnancy rates 
after PGF treatments (Galina and Arthur 1990; Moreno et al. 1986; Kerr et al. 1991; Alonso et al. 1995; Pinheiro et al. 1998). These studies emphasize the need for treatments that control follicular and luteal development to obtain high pregnancy rates to FTAI without the necessity of oestrous detection. Furthermore, treatment protocols should be capable of inducing oestrus and ovulation in anoestrus animals.

\section{GnRH-based protocols}

GnRH-based treatment protocols have been used extensively in recent years for FTAl in beef and dairy cattle (Pursley et al. 1995; 1997; Geary et al. 2001). These treatment protocols consist of an injection of GnRH followed by PGF $7 \mathrm{~d}$ later and a second injection of GnRH $48 \mathrm{~h}$ after PGF treatment. In Co-Synch protocols cows are FTAl at the time of the second GnRH (Geary et al. 2001), whereas in Ovsynch protocols, cows are FTAl $16 \mathrm{~h}$ after GnRH (Pursley etal. 1995).

The Ovsynch protocols have also been used in FTAI programs in Bos Indicus cattle (Barros et al. 2000; Lemaster et al. 2001; Williams et al. 2002; Baruselli et al. 2004). However, overall pregnancy rates have often been lower than those rates reported in Bos taurus cattle (Baruselli et al. 2004; Saldarriaga et al. 2005), with low conception rates in anoestrus cows (Fernandes et al. 2001; Baruselli et al. 2004). The addition of a progestin-releasing device increased pregnancy rates in anoestrus Bos taurus cows (Lamb et al. 2002); however, this approach has not resulted in increased pregnancy rates in Bos indicus and Bos indicus x Bos taurus crossbred cattle (Saldarriaga et al. 2005; Pincinato et al. 2006) and is probably related to a low ovulation rate following the first GnRH treatment (Saldarriaga et al. 2005).

\section{Treatments using progestins and oestradiol}

Oestradiol and progestin treatments have been increasingly used over the past several years in oestrus synchronization programs in cattle (Macmillan \& Burke 1996; Bó \& Baruselli 2002; Yelich 2002; Bo et al. 2003). Treatments consist of insertion of a progestin-releasing device and the administration of oestradiol on Day 0 (to synchronize follicular wave emergence), PGF at the time of device removal on Days 7,8 or 9 (to ensure luteolysis), and the subsequent application of a lower dose of oestradiol $24 \mathrm{~h}$ later or $\mathrm{GnRH} / \mathrm{LH} 48$ to $54 \mathrm{~h}$ later to synchronize ovulation (Bo et al. 2002a; 2002b; Martinez et al. 2002). The most commonly used treatment for FTAI using progesterone-releasing devices in beef cattle in South America consists of the administration of $2 \mathrm{mg}$ of oestradiol benzoate (EB) im upon insertion of the device (Day 0 ); on Day 7 or 8 the device is removed and PGF is administered im, and $24 \mathrm{~h}$ later, $1 \mathrm{mg}$ of EB im is given (Bó et al. 2002b); FTAl is done between 52 and $56 \mathrm{~h}$ after device removal. Data from 13,510 inseminations in Bos taurus and Bos indicus x Bos taurus crossbred cattle, performed between December 2000 and December 2004, resulted in a mean pregnancy rate of 52.7\%, ranging from $27.8 \%$ to $75.0 \%$. The factors that most affected pregnancy rates were body condition score (BCS) and cyclicity of the cows (Bó et al. 2005).

\section{Progestin based treatments for FTAl in suckled cows}

Under favourable conditions, a cow has the potential to produce one calf per year, with an interval of 12 months between calvings. However, suckled beef cattle under grazing conditions often have a high incidence of postpartum anoestrus, which extends the calving to conception interval and, consequently, negatively affects their reproductive performance. The insertion of subcutaneous norgestomet ear implants or intravaginal progesterone devices, combined with the application of eCG at the time of device removal, has been extensively used in Bos indicus herds with high incidence of postpartum anoestrus (reviewed in Baruselli et al. 
2004). The use of $400 \mathrm{IU}$ of eCG at the time of progestin device removal resulted in increased pregnancy rates in cows without a CL at the time of insertion of the progestin device (Baruselli et al. 2003; Cutaia et al. 2003a). In another study (Baruselli et al. 2004), eCG treatment increased plasma progesterone concentrations and pregnancy rates in suckled cows treated during postpartum anoestrus. Therefore, eCG treatment may be an important tool for increasing pregnancy rates at FTAI, to reduce the postpartum period, and to improve reproductive efficiency in postpartum Bos indicus and Bos indicus $\times$ Bos taurus beef cows. Analysis of data collected from 9,668 FTAI done from December 2000 through December 2003 has shown that Bos taurus and Bos indicus $x$ Bos taurus crossbred animals treated with progestin-devices must have a BCS higher than 2,5 (scale 1 to 5) and ideally $\geq 3$ to achieve pregnancy rates of $50 \%$ or higher (Bó et al. 2005). Conversely, the addition of eCG allowed for pregnancy rates close to $50 \%$ in cows with a BCS of 2 (Bó et al. 2005). It is very important to note that these results have been achieved only when cows were gaining body condition during the breeding season. If drought conditions or lack of feed prevent cattle from improving BCS during the breeding season, pregnancy rates will most probably be $35 \%$ or less, even after the administration of eCG (Cutaia et al. 2003a; Bó et al. 2005; Maraña et al. 2006). Another analysis performed with 1,987 FTAI in Nelore cows confirmed that BCS is critical to achieve pregnancy rates and that the beneficial effect of eCG treatments was significant in cows with a BCS $\leq 3$ (Fig. 1; Baruselli et al. 2005). Since BCS is usually associated with cyclicity (D'occhio et al. 1990), it is conceivable that most cows in the lower BCS were anoestrus at the time that treatments were initiated. When 485 Bos indicus $x$ Bos taurus suckled cows were examined by real time ultrasonography at the time of device insertion, pregnancy rates in cows that had a $\mathrm{CL}$ when treatments were initiated did not differ between cows treated $(56.3 \%)$ or not treated with eCG $(56.5 \%$; Bó et al. 2005). However, eCG treatments increased pregnancy rates (eCG: $49.5 \%$ vs no eCG: $40 \%$; $\mathrm{P}<0.05)$ in cows that only had follicles at the time of progestin device insertion. In yet another retrospective analysis of 2,489 FTAl in suckling Nelore cows from two commercial farms in Brazil, pregnancy rates were not different between cows that were 40 to $>80 \mathrm{~d}$ postpartum at the time of FTAI (40-49 d: 57/142, 52.8\%; 50-59 d: 419/759, 55.2\%; 60-69 d: $137 / 263,52.1 \%$, $70-79 \mathrm{~d}: 361 / 684,56.3 \%$ and $>80 \mathrm{~d}: 334 / 641,52.1 \%$; Marques et al. 2006).

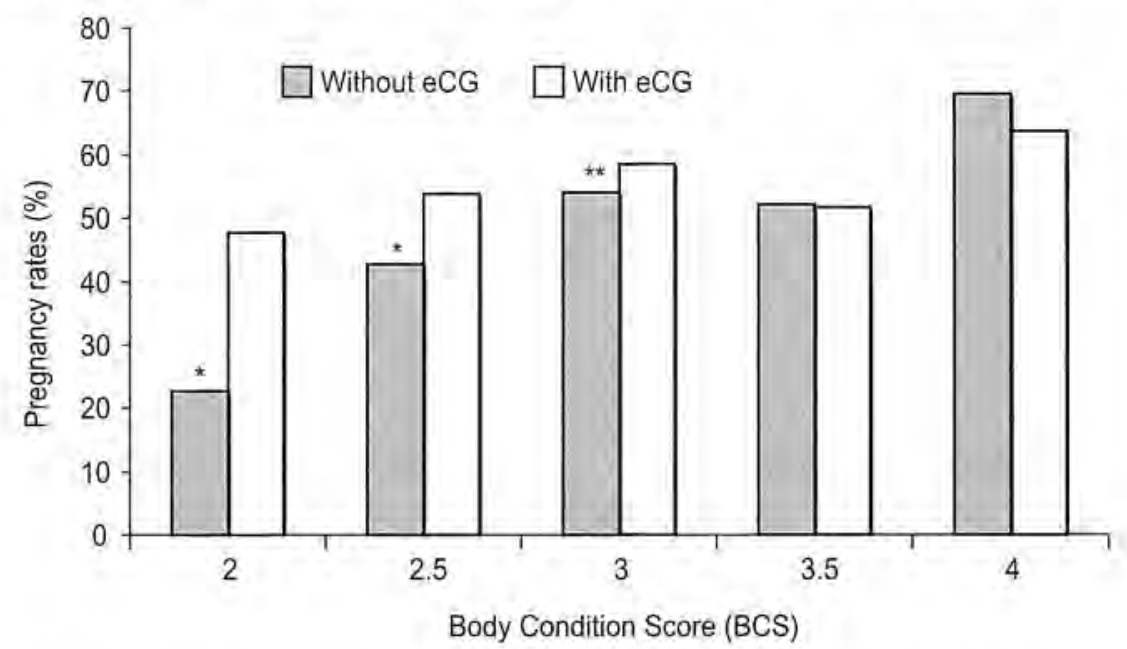

Fig. 1. Effect of body condition scores ( 1 to 5 scale) on pregnancy rates in Nelore cows $(n=1,984)$ treated with progestin-releasing devices with or without $400 \mathrm{IU}$ eCG at device removal $(* \mathrm{P}<0.05 ; * * \mathrm{P}<0.1)$. Adapted from Baruselli et al. 2005. 
Restricted suckling or calf removal associated with progestin devices has also been used for the induction of cyclicity in Bos indicus cows (Williams 1990; Soto Belloso et al. 2002). We have recently conducted two experiments to compare the effects of eCG treatment and temporary weaning (TW) on ovulation and pregnancy rates in postpartum cows. In the first experiment, 39 lactating multiparous Bos indicus x Bos taurus crossbred cows, 60 to $80 \mathrm{~d}$ postpartum with a BCS between 2.0 to 2.5 (scale 1 to 5 ) were randomly allocated to 1 of 4 treatment groups, in a 2 by 2 factorial design (Maraña et al. 2006). On Day 0, all cows received a DIB device (intravaginal progesterone-releasing device with $1 \mathrm{~g}$ of progesterone, Syntex SA, Buenos Aires, Argentina) and $2 \mathrm{mg}$ EB im (Benzoato de Estradiol, Syntex SA). On Day 8, DIB devices were removed and all cows received PGF and were randomly divided to receive $400 \mathrm{IU}$ eCG im (Novormon, Syntex SA) at the same time or no further treatment. In addition, half of the cows in each treatment group had their calves weaned for $56 \mathrm{~h}$ from the time of DIB removal; the other half remained with their calves. All cows received $1 \mathrm{mg}$ EB im on Day 9 and were examined every $8 \mathrm{~h}$ by ultrasonography, from the time of DIB removal until ovulation. The interval to ovulation (eCG, $72.0 \pm 1.4 \mathrm{~h}$ vs no eCG, $75.6 \pm 2.0 \mathrm{~h}$ and TW, $73.8 \pm 1.6 \mathrm{~h}$ vs no TW, $73.0 \pm 1.8 \mathrm{~h}$ ) did not differ among groups $(P>0.05)$. However, TW increased $(7 / 10,70.0 \% ; P<0.05)$ and eCG treatment tended to increase $(12 / 20,60.0 \% ; \mathrm{P}<0.09)$ the proportion of cows ovulating compared to control cows (no TW or eCG treatment: $2 / 9,22.2 \%$ ). Although there was no effect of eCG treatment on the size of the preovulatory follicle $(e C G, 11.1 \pm 0.4 \mathrm{~mm}$ vs no eCG, $10.1 \pm 0.6$ $\mathrm{mm})$, the growth rate of the ovulatory follicle was greater $(P<0.02)$ in cows treated with eCG $(1.1 \pm 0.1 \mathrm{~mm} / \mathrm{d})$ than in those not treated with eCG $(0.6 \pm 0.1 \mathrm{~mm} / \mathrm{d})$. Conversely, the ovulatory follicle was smaller in TW cows $(9.9 \pm 0.4 \mathrm{~mm})$, compared to those not TW $(11.8 \pm 0.3 \mathrm{~mm}$; $\mathrm{P}<0.05)$.

The second experiment was conducted over 2 years; 769 Bos indicus x Bos taurus crossbred suckled cows (year 2004, $n=393$ and year 2005, $n=376$ ) with a BCS of 2 to 2.5 were used (Maraña et al. 2006). All animals were examined by palpation per rectum at the time of initiating the treatment to determine ovarian status. Cows were randomly assigned to 4 treatment groups in a 2 by 2 factorial design (Control, eCG, TW and TW +eCG), so that cows with a CL $(22.5 \%)$, follicles $>8 \mathrm{~mm}(30.0 \%)$ or ovaries with small follicles $(<8 \mathrm{~mm} ; 47.5 \%)$ were equally represented in each group. Temporarily weaned calves were separated from their dams by approximately $1000 \mathrm{~m}$, to prevent any kind of contact between cows and calves. All cows were FTAI between 52 and $56 \mathrm{~h}$ after DIB removal. Data were analyzed by logistic regression. There was no interactions between years and treatments or between treatments $(P>0.7)$. The overall pregnancy rate was lower in $2005(109 / 376,29.0 \% ; \mathrm{P}<0.01)$ than in $2004(173 / 393$, $44.0 \%$ ), due to a drought during that breeding season; but in both years eCG treatment increased pregnancy rates (eCG, 154/377, 40.8\% vs no eCG, 128/392, 32.6\%; P<0.01). Conversely, no differences were found between cows that were TW $(141 / 379,37.2 \%)$ and those that were not $(141 / 390,36.1 \% ; P>0.7)$. It was concluded that the use of eCG but not TW improved pregnancy rates following FTAI in postpartum Bos indicus $\times$ Bos taurus crossbred cows in moderate to low body condition. Results also suggest that the eCG-related increase in pregnancy rates may be due to the final growth rate of the ovulatory follicle. On the other hand, the absence or little effect of TW on pregnancy rates contrasts with data from another study done with Nelore cows (Penteado et al. 2004), and those from other studies (reviewed in Baruselli et al. 2004). In the experiment with Nelore cows (Penteado et al. 2004), 459 suckled cows were treated with Crestar (Intervet, Sao Paulo, Brazil) for $9 \mathrm{~d}$ and were divided into 1 of 4 treatment groups to receive or not receive $400 \mathrm{IU}$ eCG im (Folligon, Intervet), and have calves TW for $56 \mathrm{~h}$ or not. In this case, both eCG and TW significantly increased $(P<0.05)$ pregnancy rates (eCG, 126/227, 55.5\% vs no eCG, 98/232 42.2\%; TW, 121/229, 52.8\% vs no TW, $103 / 230,44.8 \%$ ). Therefore, the beneficial effects of temporary weaning may differ, de- 
pending on the management and body condition of the cows. Moreover, to set up a temporary weaning program creates logistical problems in several farms and is probably the most resisted management technique by beef producers, at least in Argentina and Brazil. Nevertheless, the results from both studies confirmed those reported previously that eCG increased pregnancy rates in suckled cows enrolled in a FTAI program utilizing progestin devices and oestradiol (Cutaia et al. 2003a; Baruselli et al. 2004).

\section{Impact of Fixed-time Al programs on the overall fertility of beef herds}

One of the main advantages of implementing FTAl programs in a beef herd is that more cows can be impregnated earlier in the breeding season to genetically improved bulls, resulting in heavier weaning weights (Cutaia et al. 2003b). Fifty percent of the cows could potentially become pregnant on the first day of the breeding season and result in a higher number of cows calving at the beginning of the calving season. Therefore, their calves will be older and heavier at weaning. Besides, the use of genetically superior bulls will also result in heavier calves at weaning (Cutaia et al. 2003b). The impact of FTAI has proven to be equally efficient for different beef operations in Argentina and Brazil (Bó \& Baruselli. 2002; Baruselli et al. 2005; Bó et al. 2005) and examples will be shown in the following.

In 2002, the "Estancia El Mangrullo" (Lavalle, Santiago del Estero, Argentina) started implementing FTAI programs. This operation is located in the semiarid region of Argentina, with seasonal rainfalls of $600 \mathrm{~mm}$ per year from November-December to May-June (Summer and Fall). Animals are all zebu-derived and a cross-breeding program with Bonsmara (Bos taurus adapted breed) has been implemented with the use of semen and embryos. Table 1 shows the evolution of the number of animals involved in FTAl programs and the pregnancy rates obtained.

As shown in Table 1, a FTAI program was implemented in heifers and suckled cows which resulted in pregnancy rates between 40 and $50 \%$. It is important to highlight that the summer of 2005 (i.e. the breeding season) was especially dry, with no rains between December and March which, undoubtedly affected the pregnancy rates. However, it is apparent that an aggressive FTAI program may still result in acceptable pregnancy rates, even in the presence of the drought experienced that year. Probably, the main aspect of applying this system was its effect on calving distribution as shown in Fig. 2. The progression of calvings throughout the calving season was compared between years using Kaplan Meier's Method for comparison of survival curves. Survival curves across years were significantly different $(\mathrm{P}<0.01)$. In 2002/3 (no FTAl), calvings were distributed over 6 months with a high number of cows calving from December to March (late calvers). This was changed with the limited use of FTAI in 2003/04 (Table 1). However, with a more aggressive FTAl program, calvings began earlier, with a high proportion of heifers calving in September (i.e. $30 \mathrm{~d}$ prior to the cows) and a higher percentage of mature cows calving earlier in the breeding season (October onwards) in 2004/05.

We also evaluated the impact of FTAI on weaning weights of the calves obtained through natural service compared to that of calves obtained through FTAl in 2004 (Bó et al. 2005). Only one group of animals in which all calving data could be collected was used. The cows from the Natural Service Group were bred with Bonsmara bulls at a rate of $3 \%$ (i.e. 3 bulls per 100 cows) for $90 \mathrm{~d}$. Cows in the FTAI Group were inseminated at the beginning of the breeding season and exposed to clean-up bulls at a rate of $1.5 \%$. All cows were monitored during the calving season and calves born were identified with ear tags and weighed. Table 2 shows the weaning weights of calves produced through FTAI or natural service. Weight of the calves was adjusted to $205 \mathrm{~d}$ to determine the proportion of the weight difference between groups that was due to the age of the calves and the proportion that was due to a genetic improvement introduced with 
Table 1. Pregnancy rates following FTAl programs implemented in "Estancia El Mangrullo" in Lavalle, northeast of the Province of Santiago del Estero, Argentina. Adapled from Bó et al. 2005.

\begin{tabular}{lcccc}
\hline Category & Year 2002/03 & Year 2003/04 & Year 2004/05 & Total \\
\hline Heifers & $148 / 292$ & $341 / 619$ & $564 / 1233$ & $1053 / 2144$ \\
& $(50.7 \%)$ & $(55.1 \%)$ & $(45.7 \%)$ & $(49.1 \%)$ \\
Dry cows & - & $189 / 394$ & - & $189 / 394$ \\
Suckled cows & $156 / 289$ & $(47.9 \%)$ & & $(47.9 \%)$ \\
& $(54.0 \%)$ & $345 / 790$ & $450 / 1199$ & $951 / 2278$ \\
& & $(43.7 \%)$ & $(37.5 \%)$ & $(41.7 \%)$ \\
\hline
\end{tabular}

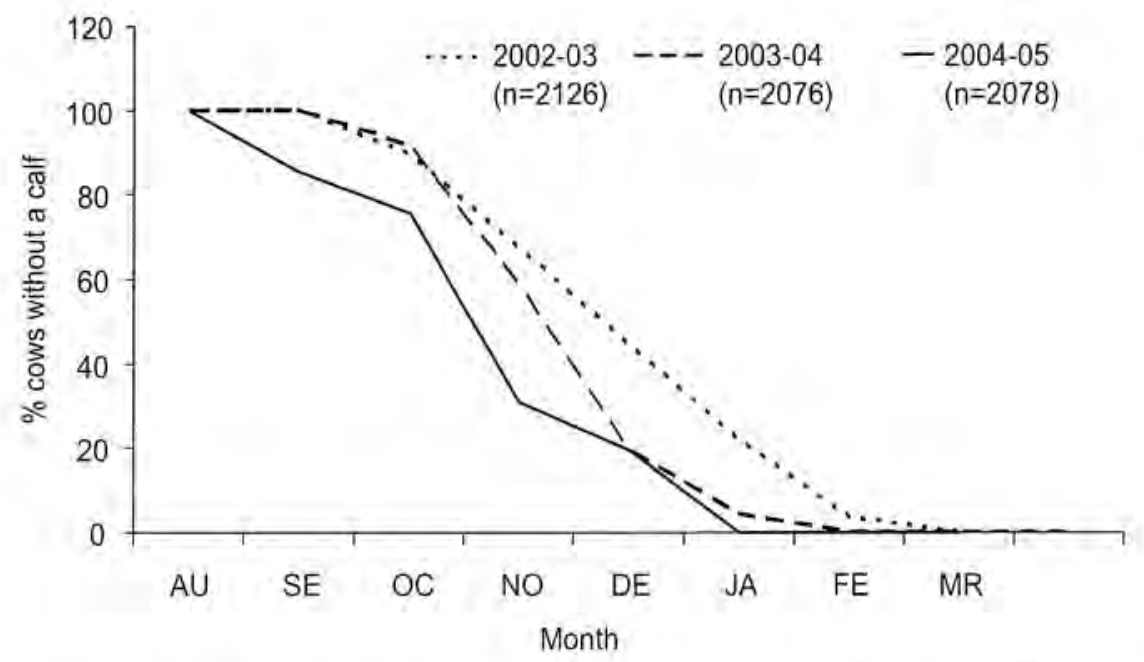

Fig. 2. Survival curves for calving distribution at "Estancia El Mangrullo" Santiago del Estero, Argentina in three consecutive years. Curves differ significantly among the three years $(P<0.01)$. Adapted from Bó et al. 2005.

Table 2. Weaning weights (means \pm SEM) of Zebu $\times$ Bonsmara calves produced through FTAl or Natural Service. "Estancia El Mangrullo", Santiago del Estero, Argentina, 2004. Adapled from Bó et al. 2005.

\begin{tabular}{lccc}
\hline & $N$ & Weaning weight $(\mathrm{Kg})$ & Adjusted 205 d-weight $(\mathrm{Kg})$ \\
\hline FTAl & 138 & $178.1 \pm 1.9^{\mathrm{b}}$ & $184.2 \pm 1.6^{\mathrm{a}}$ \\
Nafural service & 181 & $149.4 \pm 1.5^{\mathrm{b}}$ & $173.8 \pm 1.4^{\mathrm{b}}$ \\
Difference & & 28.7 & 10.4 \\
\hline
\end{tabular}

Means in the same column with different superscripts differ (at $P<0.01$ )

the bulls through FTAI. Calves from the FTAI Group were heavier at weaning than calves in the Natural Service Group. Part of this difference $(18.3 \mathrm{Kg}$ ) was attributed to age, because the calves from the FTAI Group were born earlier than those in the Natural Service Group. There was also a $10.4 \mathrm{Kg}$ weight advantage for the FTAl calves due to genetic improvement. These data confirm previous results in Angus cattle (Cutaia et al. 2003b) where differences in weaning weights were $34.6 \mathrm{Kg}$ for calves produced through FTAl compared to those produced through natural service, and showed that it was possible to improve production in a beef herd with a FTAl program at the beginning of the breeding season. 
Another study was performed in Brazil using Nelore cows (Baruselli et al. 2005). In this study, 594 suckled Nelore cows (55 to $70 \mathrm{~d}$ postpartum) were randomly allocated to 1 of 4 treatment groups. Cows in Group 1 were FTAI on Day 0 of the breeding season and were exposed to bulls for a further $90 \mathrm{~d}$. Cows in Group 2 were FTAI on Day 0 , then Al based on oestrus detection for $45 \mathrm{~d}$ and then exposed to bulls for the last $45 \mathrm{~d}$ of the breeding season. Cows in Group 3 were Al based on twice daily oestrus detection for $45 \mathrm{~d}$ and then exposed to clean-up bulls for another $45 \mathrm{~d}$. Cows in Group 4 simply were exposed to bulls for $90 \mathrm{~d}$. In order to determine the progression of the pregnancies during the breeding season, cows were examined by ultrasonography on Days 30,70 and 120 after the beginning of the breeding season. Results are shown in Table 3 and survival curves for days open are shown in Fig. 3 . The use of FTAl improved fertility by having more cows pregnant at the beginning of the breeding season. Survival curves in the FTAI + Bulls and FTAI + OED \& AI + Bulls breeding schemes differed from those in the OED \& AI + Bulls breeding schemes and the cows that were bred by bulls for the entire breeding season ( $\mathrm{P}<0.01$; Figure 3 ). Compared to the cows bred by bulls only, the insertion of FTAI hastened the mean day of conception by about $17 \mathrm{~d}$ and increased the pregnancy rates after the first $45 \mathrm{~d}$ by $30 \%$ and at the end of the breeding season by about $9 \%$ (Table 3). Conversely, the application of a traditional scheme of oestrus detection and Al for $45 \mathrm{~d}$ was the least efficient program; a reflection of the difficulty of oestrus detection in suckled Bos indicus cows.

Table 3. Reproductive parameters in suckled Nelore cows managed under four different breeding programs during a 90 d breeding season, Camapua, MS, Brazil. Adapted from Baruselli et al. 2005.

\begin{tabular}{|c|c|c|c|c|c|c|}
\hline \multirow[t]{2}{*}{$\begin{array}{l}\text { Breeding } \\
\text { strategy }\end{array}$} & \multirow{2}{*}{$\begin{array}{l}\text { FTAI } \\
\text { Pregnancy } \\
\text { rate }\end{array}$} & \multicolumn{3}{|c|}{ First $45 \mathrm{~d}$ of the breeding season } & \multicolumn{2}{|c|}{$\begin{array}{c}\text { Overall } \\
\text { (90-d breeding season) }\end{array}$} \\
\hline & & $\begin{array}{c}\text { Oestrus } \\
\text { detection rate }\end{array}$ & $\begin{array}{l}\text { Conception } \\
\text { rate }\end{array}$ & $\begin{array}{l}\text { Pregnancy } \\
\text { rate }\end{array}$ & $\begin{array}{c}\text { Pregnancy } \\
\text { rate }\end{array}$ & $\begin{array}{l}\text { Mean interval } \\
\text { to conception (d) }\end{array}$ \\
\hline $\begin{array}{l}\text { FTAI } \\
+ \text { Bulls }^{2}\end{array}$ & $\begin{array}{r}76 / 150 \\
(50.7 \%)\end{array}$ & - & - & $\begin{array}{l}113 / 150^{a} \\
(75.3 \%)\end{array}$ & $\begin{array}{l}139 / 150 \text { * } \\
(92.7 \%)\end{array}$ & $29.3 \pm 2.0$ \\
\hline $\begin{array}{l}\text { FTAI }^{1} \\
+ \text { OED \& } \mathrm{Al}^{3} \\
+ \text { Bulls }^{2}\end{array}$ & $\begin{array}{c}81 / 148 \\
(54.3 \%)\end{array}$ & $\begin{array}{c}17 / 67 \\
(25.4 \%)\end{array}$ & $\begin{array}{c}13 / 17 \\
(76.5 \%)\end{array}$ & $\begin{array}{l}94 / 148^{b} \\
(63.5 \%)\end{array}$ & $\begin{array}{l}136 / 148^{\circ} \\
(91,9 \%)\end{array}$ & $31.1 \pm 2.2^{a}$ \\
\hline $\begin{array}{l}\text { OED \& } \mathrm{Al}^{3} \\
+ \text { Bulls }^{2}\end{array}$ & - & $\begin{array}{c}59 / 150 \\
(39.3 \%)\end{array}$ & $\begin{array}{c}35 / 66 \\
(53.0 \%)\end{array}$ & $\begin{array}{l}35 / 150^{d} \\
(23.3 \%)\end{array}$ & $\begin{array}{l}125 / 147^{b} \\
(85.0 \%)\end{array}$ & $57.3 \pm 2.3^{b}$ \\
\hline Bults ${ }^{2}$ & & $=$ & - & $\begin{array}{l}66 / 149 \% \\
(44.3 \%)\end{array}$ & $\begin{array}{l}124 / 149 \% \\
(83,2 \%)\end{array}$ & $46.5 \pm 1.9$ \\
\hline
\end{tabular}

Means and percentages differ significanlly (abed, $\mathrm{P}<0.05$ ).

'FTAI: fixed-time artificial insemination on Day 10 of the breeding season.

'Bulls; bulls until Day 90 of the breeding season.

${ }^{3} \mathrm{OED} \& \mathrm{Al}$ : oestrus detection and AI until Day 45 of the breeding season.

Another example is the "Hofig Ramos Agricultura e Pecuaria", located in Brasilandia, Brazil. In this farm, an aggressive FTAI program was implemented in 5,579 suckled Nelore cows in 2005. Cows were enrolled in a FTAI program early in the postpartum period (i.e. 35 to 45 d postpartum) using Crestar ear implants and $400 \mathrm{IU}$ eCG at the time of implant removal and $10 \mathrm{~d}$ later were exposed to clean-up bulls for the remainder of the breeding season. Pregnancy rate to the FTAl was $50.5 \%(2817 / 5579)$ and the overall pregnancy rate after two cycles of re-breeding with bulls was $80.7 \%$ (4390/5579). As in the previous examples, comparison of survival curves 


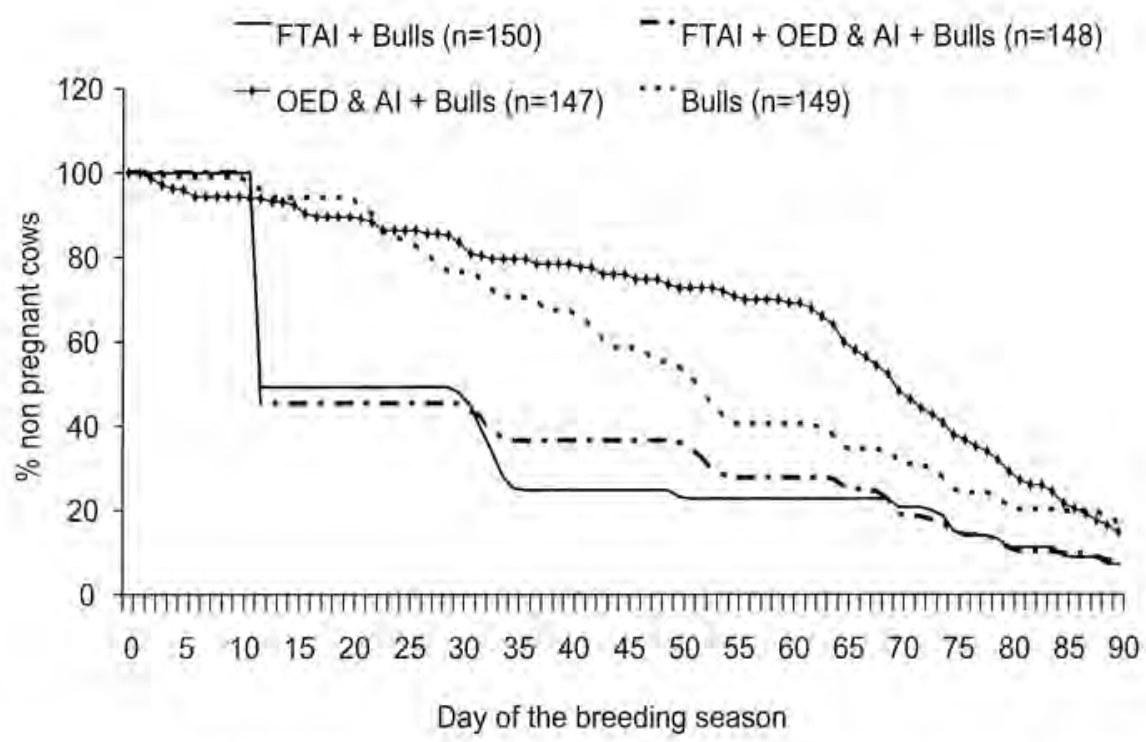

Fig. 3. Survival curves for days open in suckled Nelore cows managed under four different breeding programs during a $90 \mathrm{~d}$ breeding season, Camapua, MS, Brazil. Survival curves in the FTAI+Bulls and FTAI+OED\&AI+Bulls breeding schemes differ from the OED\&AI+Bulls and the Bulls breeding schemes $(P<0.01)$. Adapted from Baruselli el al. 2005 .

for calving distributions in 2005 and the projected calvings for 2006 confirmed the notion that the use of a progestin-based FTAI program at the beginning of the breeding season increased the number of calvings early in the calving season (Fig. 4).

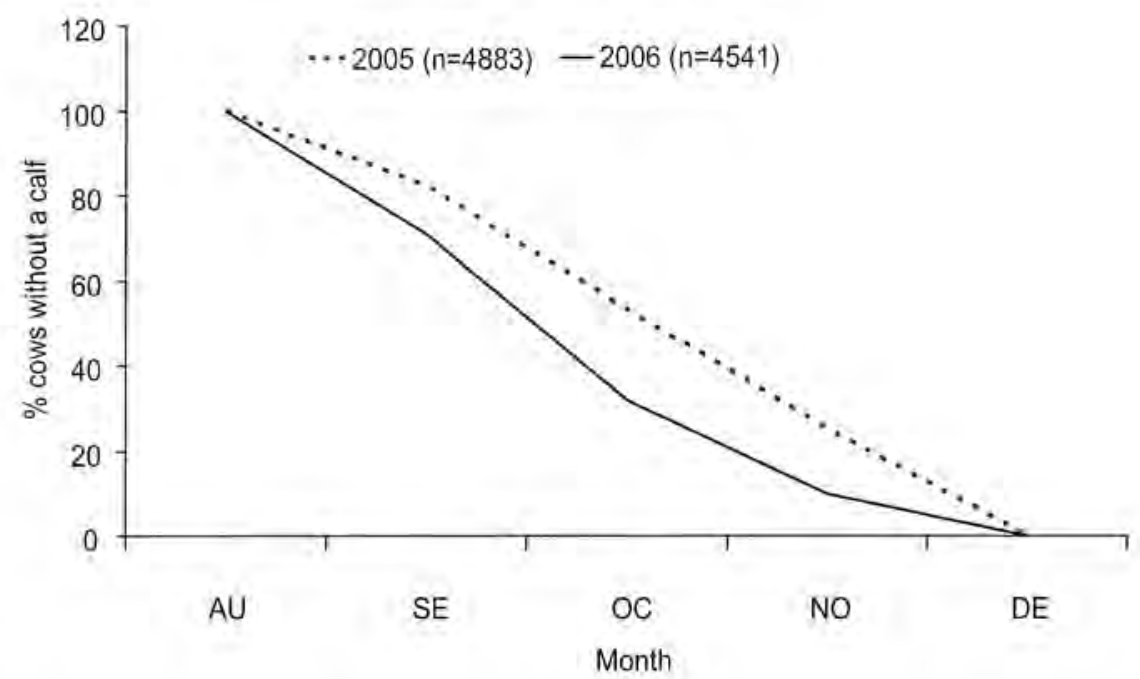

Fig. 4. Survival curves for calving distribution at "Hofig Ramós Agricultura e Pecuaria", located in Brasilandia, Brazil. Curves differ significantly between years $(\mathrm{P}<0.01)$. Marques et al. 2006. 
Another program worth mentioning is that applied at "Cabaña Ministaló", in Río Ceballos, Córdoba, Argentina. This operation is located in an area that is more temperate than the others, with about 800 to $1000 \mathrm{~mm}$ of rain per year, in a seasonal fashion from October to June. This is a mixed operation (soybean and corn crops and beef cattle) with purebred Brangus and Braford cattle (3/8 Bos indicus and 5/8 Bos taurus). Fixed-time $\mathrm{Al}$ has been done in November and December of the last 5 years in 22 to 26 month old heifers and suckled cows that were 45 to 70 $\mathrm{d}$ postpartum. In this herd, animals have always been in good BCS ( 2.5 to 3.5 ) at the beginning of the breeding season; the FTAl treatment consisted of a progesterone-releasing device (Triu$\mathrm{B}, 1 \mathrm{~g}$ of progesterone, Biogénesis, Argentina; DIB, $1 \mathrm{~g}$ of progesterone, Syntex SA, Argentina or CIDR-B, $1.9 \mathrm{~g}$ of progesterone, Pfizer Animal Health, Argentina), with $2 \mathrm{mg}$ EB on Day 0 , device removal and PGF on Days 7 or $8,1 \mathrm{mg}$ EB $24 \mathrm{~h}$ later and FTAI from 52 to $56 \mathrm{~h}$ after device removal. As the goal was to increase the number of offspring produced by $\mathrm{Al}$, animals were re-synchronized by re-insertion of the progesterone-releasing device on Day 13 after FTAI. EB (1 mg im) was also given to cows (but not to heifers) on Day 13. In this case, oestrus was detected for $5 \mathrm{~d}$ after device removal (Days 20 to 25 after the first FTAI) and all animals were inseminated 8 to $12 \mathrm{~h}$ after the onset of oestrus. As is shown in Table 4, pregnancy rates with FTAI were similan over the 5 years $(P>0.88)$. Overall pregnancy rates with $A l$ decreased during 2004 ( $P<0.05)$, compared to the two previous years, due to failures in oestrus detection after the re-synchronization protocol, which demonstrates the sensitivity of systems that depend on oestrus detection in beef cattle. This was corrected in 2005 by the use of a re-synchronization protocol that included a second FTAI. Briefly, the re-synchronization treatment consisted of re-insertion of a once-used progesterone-releasing device from Day 16 to Day 21 and GnRH was given on Day 21. On Day 28, all cows and heifers were examined by ultrasonography and those that were open received PGF at that time, followed by $1 \mathrm{mg}$ EB im $24 \mathrm{~h}$ later and FTAI $30 \mathrm{~h}$ after EB. As is shown in Table 4, avoiding oestrus detection for the second Al overcame the problem and approximately $70 \%$ of the cows were pregnant after two inseminations.

Table 4. Pregnancy rales with FTAI, oestrus detection rate, conception and pregnancy rates following resynchronization and overall pregnancy rates on a purebred Brangus and Braford farm, "Cabaña Ministaló", Córdoba, Argentina. Adapted from Bó et al. 2005.

\begin{tabular}{|c|c|c|c|c|c|}
\hline \multirow[t]{2}{*}{ Year } & \multirow[t]{2}{*}{ Pregnancy rate FTAI } & \multicolumn{3}{|c|}{ Re-synchronization } & \multirow{2}{*}{ Cumulative pregnancy rate } \\
\hline & & $\begin{array}{c}\text { Qestrus detection } \\
\text { rate }\end{array}$ & $\begin{array}{c}\text { Conception } \\
\text { rate }\end{array}$ & $\begin{array}{c}\text { Pregnancy } \\
\text { rale }\end{array}$ & \\
\hline 2001 & $\begin{array}{l}107 / 189 \\
(56.6 \%)\end{array}$ & $\begin{array}{l}44 / 82 \text { b } \\
(53.7 \%)\end{array}$ & $\begin{array}{c}24 / 44 \\
(54.5 \%)\end{array}$ & $\begin{array}{l}24 / 82 \text { 屯 } \\
(29.3 \%)\end{array}$ & $\begin{array}{c}131 / 189 \% \\
(69,3 \%)\end{array}$ \\
\hline 2002 & $\begin{array}{l}104 / 192 \\
(51.2 \%)\end{array}$ & $\begin{array}{l}49 / 88 \text { b } \\
(55.7 \%)\end{array}$ & $\begin{array}{l}35 / 49 \\
(71.4 \%)\end{array}$ & $\begin{array}{l}35 / 88^{b} \\
(39.7 \%)\end{array}$ & $\begin{array}{l}139 / 192^{6} \\
(72+4 \%)\end{array}$ \\
\hline 2003 & $\begin{array}{l}128 / 228 \\
(56.1 \%)\end{array}$ & $\begin{array}{l}71 / 100^{b} \\
(71.0 \%)\end{array}$ & $\begin{array}{c}36 / 71 \\
(50.7 \%)\end{array}$ & $\begin{array}{l}36 / 100^{b} \\
(36.0 \%)\end{array}$ & $\begin{array}{c}164 / 228^{6} \\
(71,9 \%)\end{array}$ \\
\hline 2004 & $\begin{array}{l}149 / 279 \\
(53.4 \%)\end{array}$ & $\begin{array}{l}50 / 130 \text { a } \\
(38.4 \%)\end{array}$ & $\begin{array}{c}25 / 50 \\
(50.0 \%)\end{array}$ & $\begin{array}{l}25 / 130 \\
(19.2 \%)\end{array}$ & $\begin{array}{l}174 / 279 \text { a } \\
(62,4 \%)\end{array}$ \\
\hline $2005^{\prime}$ & $\begin{array}{l}164 / 309 \\
(53.1 \%)\end{array}$ & - & - & $\begin{array}{l}65 / 145^{b} \\
(44.8 \%)\end{array}$ & $\begin{array}{c}229 / 309^{b} \\
(74.1 \%)\end{array}$ \\
\hline Total & $\begin{array}{c}652 / 1197 \\
(54.5 \%)\end{array}$ & $\begin{array}{l}214 / 400 \\
(53.5 \%)\end{array}$ & $\begin{array}{l}120 / 214 \\
(56.1 \%)\end{array}$ & $\begin{array}{l}185 / 544 \\
(34.0 \%)\end{array}$ & $\begin{array}{c}837 / 1197 \\
(69.9 \%)\end{array}$ \\
\hline
\end{tabular}

\footnotetext{
ath Proportions in the same column with different superscripts differ $(P<0.05)$.

' In 2005 cows and heifers were not observed for oestrus and were re-inseminated based on a FTAI protocol.
} 


\section{Conclusions}

Currently, the world's economic situation requires efficient management practices to increase the profitability of beef cattle operations. Optimal reproductive efficiency is crucial to increase net returns. The use of animal breeding technologies has become of great importance, particularly in tropical and subtropical areas where $\mathrm{Al}$ is the only alternative to introduce Bos taurus genetics into Zebu-based herds. However, variability in response to the traditional PGF-based hormonal treatments and the time and effort required to perform oestrus detection, particularly in Bos indicus influenced cattle, have limited the widespread application and success of these technologies. The incorporation of techniques designed to control follicular wave dynamics and ovulation in recent years has reduced problems associated with oestrus detection. Furthermore treatments with progestin-releasing devices, oestradiol and eCG have provided possibilities for the application of FTAl in suckled cows and to advance the resumption of cyclicity in cows that were in anoestrus. Furthermore, fertility in successive cycles and overall pregnancy rates at the end of the breeding season have been shown to improve with the use of progestinreleasing devices at the beginning of the breeding season in cows that were well managed and on an increasing plane of nutrition. However, it is very important to recognize that the success of the program will also depend on many management factors such as the nutritional and health management, availability of qualified personnel, facilities and the objectives of the breeding program.

\section{Aknowledgments}

Research was supported by FAPESP, Brazil (08363-0/2002), the Instituto de Reproducción Animal Córdoba (IRAC) and Estancia "El Mangrullo S.A.", Argentina. We also thank Syntex S,A., Argentina; Biogenesis, Argentina; Pfizer Animal Health, Argentina and Brazil; Intervet, Brazil and Tecnopec, Brazil for the hormones used in the studies. Special thanks to our colleagues of IRAC, U. of São Paulo, GeraEmbryo and FIRMASA IATF for technical assistance. e-mail: gabrielbo@iracbiogen.com.ar

\section{References}

Alonso A, Mapletoft RJ, Bó GA, Tribulo HE, Carcedo J, Tribulo R \& Menajovsky JR 1995 Niveles de hormona luteinizante $y$ de estrógeno en hembras bos indicus tratadas con prostaglandina F2a. Resultados preliminares, XIV Reunión Latinoamericana de Producción Animal, Mar del Plata, Argentina, Revista Argentina de Producción Animal 15 961-963.

Barros CM, Figueiredo RA \& Pinheiro OL 1995 Estro, ovulação e dinâmica folicular em zebuínos. Revista Brasileira de Reproduçâo Animal 19 9-22.

Barros CM, Moreira, MBB, Figueiredo RA, Teixeira AB \& Trinca LA 2000 Synchronization of ovulation in beef cows (Bos indicus), using GnRH, PGF2a and estradiol benzoate. Theriogenology 53 1121-1134.

Baruselli PS, Marques MO, Nasser LF, Reis EL \& Bó GA 2003 Effect of eCG on pregnancy rates of lactating zebu beef cows treated with CIDR-B devices for timed artificial insemination. Theriogenology 59214.

Baruselli PS, Reis EL, Marques MO, Nasser LF \& Bó GA 2004 The use of treatments to improve reproductive performance of anestrus beef cattle in tropical climates. Animal Reproduction Science 82-83 479-486.

Baruselli PS, Bó GA, Reis EL, Marques MO \& Sá Filho MF 2005 Introdução da IATF no manejo reproductivo dé rebanhos bovinos de corte no Brasil. Proc VI Simposio Internacional de Reproducción Animal, June 24-26 2005, Córdoba, Argentina, pp 151-176.

Bertram Membrive CM 2000 Estudo da sincronizaçāo das ondas foliculares e das caracteristicas de estros, por radio telemetría, em novilhas cruzadas (Bos indicus $\times$ Bos taurus) tratadas com acelato de melengestrol e prostaglandina associados a hCG, GnRH ou 17 â estradiol + progesterona. Tesis de Maestría. Universidade de São Paulo, Faculdade de Medicina Veterinária e Zootecnia, Sào Paulo, SP, Brazil.

Bó GA \& Baruselli PS 2002 Programas de Inseminaciốn Artificial a Tiempo Fijo en el Ganado Bovino en Regiones Subtropicales y Tropicales. Capítulo XXXI. In Avances en la Gandería doble propósito, pp 499- 
514. Eds C Gonzalez-Stagnaro, E Soto Belloso \& L Ramírez Iglesia. Maracaibo, Venezuela: Fundación Girarz.

Bó GA, Cutaia L \& Tribulo R 2002a Tratamientos hormonales para inseminación artificial a tiempo fijo en bovinos para carne: algunas experiencias realizadas en Argentina. Primera Parte. Taurus 14 10-21.

Bó GA, Cutaia L \& Tribulo R. 2002b. Tratamientos hormonales para inseminación artificial a tiempo fijo en bovinos para carne: algunas experiencias realizadas en Argentina. Segunda Parte. Taurus 15 $17-32$

Bó GA, Baruselli PS \& Martinez MF 2003 Pattern and manipulation of follicular development in Bos indicus cattle. Animal Reproduction Science 78 307-326.

Bó GA, Cutaia L, Chesta P, Balla E, Pincinato D, Peres L, Maraña D, Avilés M, Menchaca A, Veneranda G \& Baruselli PS 2005 Implementacion de programas de inseminación artificial en rodeos de cría de argentina. Proc VI Simposio Internacional de Reproducción Animal, june 24-26 2005, Córdoba, Argentina, pp 97-128.

Chenoweth PI 1994 Aspects of reproduction in female Bos indicus cattle: a review. Australian Veterinary Journal 71 422-426.

Cutaia L, Tribulo R, Moreno D \& Bó GA 2003a Pregnancy rates in lactating beef cows Ireated with proges. terone releasing devices, estradiol benzoate and equine chorionic gonadotropin (eCG). Theriogenology 59216.

Cutaia L, Veneranda G, Tribulo R, Baruselli PS \& Bó GA 2003 b Programas de Inseminación Artificial a Tiempo Fijo en Rodeos de Cría: Factores que lo Afectan y Resultados Productivos. Proc V Simposio Internacional de Reproducción Animal. June 25-27 2003, Huerta Grande, Córdoba, Argentina, pp 119-132.

D'Occhio MJ, Neish A \& Broadhurst L 1990 Differences in gonadotrophin secretion postpartum beIween Zebu and European breed cattle. Animal Reproduction Science 22 311-317.

Fernandes P, Teixeria AB, Crocci AJ \& Barros CM 2001 Timed artificial insemination in beef cattle using GnRH agonist, PGF2a and estradiol benzoate (EB). Theriogenology 55 1521-1532.

Galina CS \& Arthur GH 1990 Review on cattle reproduction in the tropics. Part 4. Oestrus cycles. Animal Breeding Abstracts 58 697-707.

Galina CS, Orihuela A \& Rubio 11996 Behavioural trends affecting oestrus detection in Zebu cattle. Animal Reproduction Science 42 465-470.

Gimenes LU, Carvalho NAT, Sá Filho MF, Santiago LL, Carvalho JBP, Mapletoft RJ, Barros CM \& Baruselli PS 2005a Capacidade ovulatória em novilhas bos indicus. Acta Scientiae Veterinariae 33 (Supplement) 209.

Gimenes LU, Sá Filho MF, Madure EH, Trinca LA, Barros CM, Baruselli PS 2005 b Estudo ultrasonográfico da divergência folicular em novilhas Bos indicus. Acta Scientiae Veterinariae 33 (Supplement) 210.
Ginther OJ, Wiltbank MC, Fricke PM, Gibbons JR \& Kot K 1996 Selection of the dominant follicle in cattle. Biology of Reproduction 551187-1194.

Geary TW, Whittier JC, Hallford DM \& MacNeil MD 2001 Calf removal improves conception rates to the Ovsynch and Co-synch protocols. Journal of Animal Science 79 1-4.

Kastelic JP \& Ginther OJ 1991 Factors affecting the origin of the ovulatory follicle in heifers with induced luteolysis. Animal Reproduction Science 26 13-24.

Kerr DR, McGowan MR, Carroll CL, Baldock FC 1991 Evaluation of three estrus synchronization regimens for use in extensively managed bos-indicus and bos indicus/taurus heifers is norlhern Australia. Theriogenology 36 129-138.

Lamb GC, Stevenson JS, Kesler DJ, Garverick HA, Brown DR, Salfen BE 2002 Inclusion of an intravaginal progesterone inserl plus $\mathrm{GnRH}$ and prostaglandin F2 $\alpha$ ovulation control in postpartum suckled beef cows. Journal of Animal Science 79 2253-2259.

Lemaster IW, Yelich JV, Kempfer JR, Fullenwider JK, Barnett CL, Fanning MD, Selph, IF 2001 Effectiveness of GnRH plus prostaglandin F2a for estrus synchronization in caltle of Bos indicus breeding. lournal of Animal Science 79 309-316.

Macmillan KL \& Burke CR 1996 Effects of oestrus cycle control on reproductive efficiency. Animal Reproduction Science 42 307-320.

Maraña D, Cutaia L, Peres L, Pincinato D, Borges LFK \& Bó GA 2006 Qvulation and pregnancy rates in postpartum bos indicus cows treated with progesterone vaginal devices and estradiol benzoate, with or without eCG and temporary weaning. Reproduction Fertility and Development 18 116-117.

Marcantonio SA 2003 El mercado del semen bovino en Argentina. Taurus 19 11-17.

Martinez MF, Kastelic JP, Adams GP \& Mapletoft RJ 2002 The use of a progesterone-releasing device (CIDR) or melengestrol acetate with $\mathrm{GnRH}, \mathrm{LH}$ or estradiol benzoate for fixed-time $\mathrm{Al}$ in beef heifers. Journal of Animal Science 80 1746-1751.

McGowan MR 1999 Sincronización de celos y programas de inseminación artificial a tiempo fijo en ganado bos-indicus y cruza bos indicus. Proc III Simposio Internacional de Reproducción Animal, fune 19-21 1999, Carlos Paz, Córdoba, Argentina, pp 71 82.

Mizuta K 2003 Estudo comparativo dos aspectos comportamentais do estro e dos teores plasmáticos de LH, FSH, progesterona e estradiol que precedem a ovulação em fêmeas bovinas Nelore (Bos taurus indicus), Angus (Bos taurus taurus) e Nelore $\times$ Angus (Bos taurus indicus $\times$ Bos taurus taurus), PhD Thesis. Universidade de Sào Paulo, Faculdade de Medicina Veterinária e Zootecnia, São Paulo, SP, Brazil.

Moreno I, Galina CS, Escobar FI, Ramirez B \& NavarroFierro R 1986 Evaluation of the Iytic response of PGF $2 \alpha$ in Zebu cattle based on serum progesterone. Theriogenology 25 413-421. 
Odde KG 1990 A review of synchronization of estrus in postpartum cattle, Journal of Animal Science 68817 830 .

Penteado L, Ayres H, Madureira E.H. \& Baruselli PS 2004 Efeíto do desmame temporário na laxa de prenhez de vacas Nelore lactantes inseminadas em tempo fixo. Acta Scientiae Veterinariae 32 (Supplement) 223.

Pincinato D, Coelho Peres L, Miranda G, Cutaia L \& Bó GA 2006 Follicular dymanics and fertility in beef suckled cows synchronized with progesterone releasing devices and GnRH. Acta Scientiae Veterinariae 33 (Supplement) Submitted.

Pinheiro OL, Barros CM, Figueredo RA, Valle ER, Encarnação RO \& Padovani CR 1998 Estrous behaviour and the estrus-to-ovulation interval in Nelore caltle (Bos indicus) with natural estrus or estrus induced with proslaglandin $F 2 \alpha$ or norgestomet and estradiol valerate. Theriogenology $49667-681$.

Pursley IR, Mee MO \& Wiltbank MC 1995 Synchronization of ovulation in dairy cows using PGF2á and GnRH. Theriogenology 44 915-923.

Pursley JR, Wiltbank MC, Stevenson JS, Ottobre IS, Garverick HA \& Anderson LL 1997 Pregnancy rates per artificial insemination for cows and heifers inseminated at a synchronized ovulation or synchronized estrus. Journal of Dairy Science $\mathbf{8 0}$ 295-300.

Randel RD 1984 Seasonal effects on female reproductive functions in the bovine (Indian breeds). Theriogenology 21 170-185.

Randel RD 1994 Unique reproduclive traits of Brahman and Brahman based cows. In: Factors affecting calf crop, pp 23-43. Eds MJ Field \& RS Sand. Boca Ratón, FL, USA: CRC Press.

Rocha JL 2000 Sincronizaçào hormonal da onda folicular e do estro em novilhas de corte mestiças monitoradas por radio telemetria. Thesis Doctoral. Universidade de São Paulo, Faculdade de Medicina Veterinária e Zootecnia, Sâo Paulo, SP, Brazil.

Ruiz-Cortes ZT \& Olivera-Angel M 1999 Ovarian follicular dynamics in suckled zebu (Bos indicus) cows monitored by real time ultrasonography. Animal Reproduction Science 54 211-220.

Saldarriaga JP, Cooper DA, Cartmill JA, Stanko RL \& Williams GL 2005 Sincronización de la ovulación e inseminación artificial a tiempo fijo en ganado cruza bos indicus en Estados Unidos, VI Simposio Internacional de Reproducciôn Animal, June 24-26, Córdoba, Argentina, pp 97-128.

Sartorelli ES, Carvalho LM, Bergfelt DR, Ginther OJ \& Barros CM 2005 Morphological characterization of follicle deviation in Nelore (Bos indicus) heifers and cows. Theriogenology $2005632382-2394$.

Sartori R, Fricke PM, Ferreira JCP, Ginther OJ \& Wiltbank MC 2001 Follicular deviation and acquisition of ovulatory capacity in bovine follicles, Biology of Reproduction 65 1403-1409.

Segerson EC, Hansen TR, Libby DW, Randel RD \& Getz WR 1984 Ovarian and uterine morphology and function in Angus and Brahman cows, /ourinal of Animal Science 59 1026-1046.

Soto Belloso E, Portillo Martinez G, De Ondiz A, Rojas N, Soto Castillo G, Ramírez Iglesia L, Perea Ganchou F 2002 Improvement of reproductive performance in crossbred zebu anestrus suckled primiparous cows by treatment with norgestomet implants or $96 \mathrm{~h}$ calf removal. Theriogenology 57 1503-1510.

Stahringer RC, Neuendorff DA \& Randel RD 1990 Seasonal variations in characteristics of estrous cycles in pubertal Brahman heifers. Theriogenology 34407 , 415.

Williams GL 1990 Suckling as a regulator of posparlum rebreeding in cattle. A review. Journal of Animal Science 68 831-852.

Williams SW, Stanko RL, Amstalden M, Williams GL 2002 Comparison of three approaches for synchronization of ovulation for timed artificial insemination in Bos indicus-influenced cattle managed on the Texas gulf coast. Journal of Animal Science $801173-$ 1178.

Wiltbank MC, Gumen A, Sartori R 2002 Physiological classification of anovulatory conditions in caltle. Theriogenology 57 21-52.

Yelich JV 2002 A vaginal insert (CIDR) to synchronize estrus and timed-AI. In: Factors affecting call crop: biotechnology of reproduction, pp 87-100. Eds MJ Fields, RS Sands \& JV Yelich. Boca Raton, FL USA: CRC Press. 